\title{
Mucosal secretory IgA and secretory piece in adult coeliac disease
}

\author{
R. J. SHINER AND JANET BALLARD ${ }^{1}$ \\ From the Medical Research Council Gastroenterology Unit, Central Middlesex Hospital, Park Royal, London
}

SUMMARY Immunofluorescence studies with specific antisera to secretory $\operatorname{IgA}(11 \mathrm{~S} \operatorname{IgA})$ and secretory piece were carried out on the jejunal mucosa of nine patients with adult coeliac disease (treated and untreated). The results were compared with those obtained in four normal patients and in four patients with local and systemic IgA (7S) deficiency. 11S IgA and secretory piece were localized to the upper third of the epithelial cells of both surface and glandular epithelium in all groups of patients. However, in the untreated coeliac patients fluorescence was also demonstrated in the basement membrane and connective tissue of the mucosa (returning to normal on treatment).

On the basis of our findings, a revised pathway for the normal production of 11S IgA is proposed as well as an additional pathway involving a 'backflow' of $11 \mathrm{~S} \operatorname{IgA}$ into the lamina propria in pathological states such as coeliac disease. This backflow is reversed by an adequate gluten-free diet. It is suggested that 7S IgA and 11S IgA may be involved in immune reactions in the mucosa with antigens such as gluten.

The major antibody found in human secretions is secretory IgA (11S) which differs from serum IgA (7S) in having a higher molecular weight and thus a higher sedimentation coefficient (11S rather than 7S) (Tomasi, Tan, Solomon, and Prendergast, 1965). This increase is due to a component known as secretory piece, a glycoprotein found in the gastrointestinal epithelial cells (South, Cooper, Wollheim, Hong, and Good, 1966; Hanson and Johannson, 1967; Tomasi and Bienenstock, 1968; Tourville, Adler, Bienenstock, and Tomasi, 1969).

The $11 \mathrm{~S} \mathrm{IgA}$ is formed from a dimer of $7 \mathrm{~S}$ IgA and one molecule of secretory piece and this combination is thought to occur in the vicinity of epithelial cells (Tourville et al, 1969) before the antibody reaches the lumen. Unlike $7 \mathrm{~S} \operatorname{IgA}, 11 \mathrm{~S}$ IgA is resistant to digestion by trypsin (Cederblad, Johannson, and Rymo, 1966; Brown, Newcomb, and Ishizaka, 1970; Steward, 1971), thus retaining its antibody activity in the jejunal juice where the action may be directed against bacteria (Tourville, Bienenstock, and Tomasi, 1968; Girard and Kalbermatten, 1970), viruses (Balázs and Szöllösy, 1962; Lipton and Steigman, 1963), parasites (Parkin,

'Send requests for reprints to J.B.

Received for publication 3 July 1973.
McClelland, O'Moore, Percy-Robb, Grant, and Shearman, 1972), and dietary constituents (Davis, Bierman, Pierson, Maas, and Iannetta, 1970; Ferguson and Carswell, 1972).

However, the transfer of $11 \mathrm{~S} \operatorname{IgA}$ cannot be entirely unidirectional from epithelial cells to the lumen since several authors (Thompson, Asquith, and Cooke, 1969; Waldman, Mach, Stella, and Rowe, 1970; Thompson and Asquith, 1970; Brandtzaeg, 1971) have demonstrated it in minute amounts in the serum of healthy subjects, and in higher concentrations in various gastrointestinal diseases, including coeliac disease.

Loeb, Strober, Falchuk, and Laster (1971) demonstrated an increased synthesis of IgA, and also of IgM, by mucosal immunocytes in the adult coeliac patients after the re-introduction of gluten to their diets. In our previous publication (Shiner and Ballard, 1972b), IgA was shown to be involved in the formation of immune complexes in the jejunal mucosa of treated coeliac children after challenge with gluten. It was assumed that the only IgA involved was $7 \mathrm{~S}$, but the demonstration of increased amounts of 11S IgA in the sera of patients with adult coeliac disease (Thompson et al, 1969) prompted us to re-investigate the type of IgA found in the jejunal mucosa of these patients. 
This paper demonstrates that $11 \mathrm{~S} \mathrm{IgA}$ and possibly also free secretory piece are found in the lamina propria of untreated coeliac patients. That 11S IgA may be involved in subepithelial immune reactions would seem to be a new concept.

\section{Materials and Methods}

Nine patients with adult coeliac disease were studied, two of whom were biopsied before and after treatment (table 1). They were aged 16 to 56 years, (average 35 years). Four patients were untreated (nos. 1, 2, 3, and 4), and patient no. 5 had been on oral prednisone only. All five had a subtotal villous atrophy of the jejunal mucosae. Six patients (nos. $1,4,6,7,8$, and 9) were studied after treatment with a gluten-free diet. Five of these showed a mild partial villous atrophy on histology, but the sixth (no. 6), who admitted to dietary errors, had a patchy partial and subtotal villous atrophy.

The jejunal biopsies from eight non-coeliac patients, aged 13 to 59 (average 37 years), served as controls (table II). In four of these (nos. 10, 11, 12, and 13), gastrointestinal disease was ruled out and the jejunal mucosa was normal. The other four (nos. 14, 15,16 , and 17) had local and systemic immune deficiency disease with histological normal villous architecture.

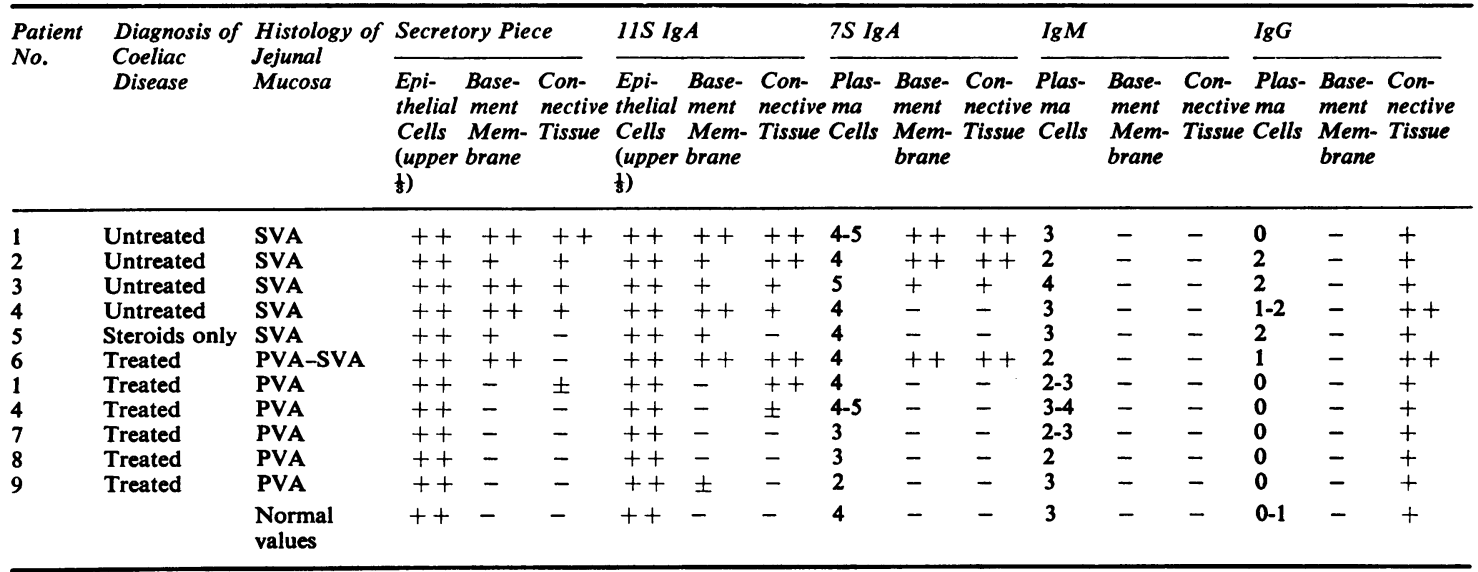

Table I Immunofluorescence results in coeliac disease untreated and treated

SVA-Subtotal villous atrophy

PVA-Partial villous atrophy

$$
\begin{gathered}
++ \text {-strongly positive } \\
+ \text {-positive } \\
\pm \text { - weakly positive }
\end{gathered}
$$

\begin{tabular}{|c|c|c|c|c|c|c|c|c|c|c|c|c|c|c|c|c|c|}
\hline \multirow{2}{*}{$\begin{array}{l}\text { Patient } \\
\text { No. }\end{array}$} & \multirow[t]{2}{*}{ Diagnosis } & \multirow{2}{*}{$\begin{array}{l}\text { Histology of } \\
\text { Jejunal } \\
\text { Mucosa }\end{array}$} & \multicolumn{3}{|c|}{ Secretory Piece } & \multicolumn{3}{|c|}{$11 S \operatorname{Ig} A$} & \multicolumn{3}{|c|}{$7 S \operatorname{Ig} A$} & \multicolumn{3}{|l|}{$I g M$} & \multicolumn{3}{|l|}{$\operatorname{Ig} G$} \\
\hline & & & $\begin{array}{l}\text { Epi- } \\
\text { thelial } \\
\text { Cells } \\
\text { (upper } \\
\text { f) }\end{array}$ & $\begin{array}{l}\text { Base- } \\
\text { ment } \\
\text { Mem- } \\
\text { brane }\end{array}$ & $\begin{array}{l}\text { Conn- } \\
\text { nective } \\
\text { Tissue }\end{array}$ & $\begin{array}{l}\text { Epi- } \\
\text { thelial } \\
\text { Cells } \\
\text { (upper } \\
\left.\frac{1}{8}\right)\end{array}$ & $\begin{array}{l}\text { Base- } \\
\text { ment } \\
\text { Mem- } \\
\text { brane }\end{array}$ & $\begin{array}{l}\text { Con- } \\
\text { nective } \\
\text { Tissue }\end{array}$ & $\begin{array}{l}\text { Plas- } \\
\text { ma } \\
\text { Cells }\end{array}$ & $\begin{array}{l}\text { Base- } \\
\text { ment } \\
\text { Mem- } \\
\text { brane }\end{array}$ & $\begin{array}{l}\text { Con- } \\
\text { nective } \\
\text { Tissue }\end{array}$ & $\begin{array}{l}\text { Plas- } \\
\text { ma } \\
\text { Cells }\end{array}$ & $\begin{array}{l}\text { Base- } \\
\text { ment } \\
\text { Mem- } \\
\text { brane }\end{array}$ & $\begin{array}{l}\text { Con- } \\
\text { nective } \\
\text { Tissue }\end{array}$ & $\begin{array}{l}\text { Plas- } \\
\text { ma } \\
\text { Cells }\end{array}$ & $\begin{array}{l}\text { Base- } \\
\text { ment } \\
\text { Mem- } \\
\text { brane }\end{array}$ & $\begin{array}{l}\text { Con- } \\
\text { nective } \\
\text { Tissue }\end{array}$ \\
\hline 10 & Normal & Normal & ++ & - & - & ++ & - & - & 4 & - & - & 3 & - & - & 0 & - & + \\
\hline 11 & Normal & Normal & ++ & - & - & ++ & - & - & 3 & - & - & 3 & - & - & 0 & - & + \\
\hline 12 & Normal & Normal & ++ & - & - & ++ & - & - & 4 & - & - & 2 & - & - & 0 & - & + \\
\hline 13 & Normal & Normal & ++ & - & - & ++ & - & - & 4 & - & - & $3-4$ & - & - & 1 & - & + \\
\hline 14 & $\begin{array}{l}\text { Hypogamma- } \\
\text { globulinaemia } \\
\text { with NLH }\end{array}$ & Normal & ++ & - & - & ++ & - & - & $1-2$ & - & - & 3 & - & - & 0 & - & + \\
\hline 15 & $\begin{array}{l}\text { IgA \& IgG } \\
\text { deficiency }\end{array}$ & Normal & ++ & - & - & ++ & - & - & 0 & - & - & $2-3$ & - & - & 0 & - & - \\
\hline 16 & $\begin{array}{l}\text { A-gamma- } \\
\text { globulinaemia }\end{array}$ & $a^{\text {Normal }}$ & ++ & - & - & ++ & - & - & 0 & - & - & 0 & - & - & 0 & - & - \\
\hline \multirow[t]{2}{*}{17} & $\begin{array}{l}\text { A-gamma- } \\
\text { globulinaemia }\end{array}$ & Normal & ++ & - & - & ++ & - & - & $\mathbf{0}$ & - & - & 0 & - & - & 0 & - & - \\
\hline & & $\begin{array}{l}\text { Normal } \\
\text { values }\end{array}$ & ++ & - & - & ++ & - & - & 4 & - & - & 3 & - & - & $0-1$ & - & + \\
\hline
\end{tabular}

Table II Immunofluorescence results in control patients 
Jejunal mucosal biopsies (Crosby capsule) were performed on all patients as a diagnostic procedure and part of each specimen was retained, immediately frozen in liquid nitrogen, and stored at $-80^{\circ} \mathrm{C}$ for immunofluorescence studies.

The antisera to $11 \mathrm{~S}$ IgA and secretory piece (Nordic Pharmaceuticals), both raised in sheep, were purified before use by precipitation with $\mathbf{4 0}$ and $50 \%$ ammonium sulphate and dialysis, giving a single gamma globulin band on electrophoresis. The specificity of both antisera was tested by immunoelectrophoresis (fig 1). Precipitin lines identified for IgA and secretory piece excluded the possibility of reactions with other serum or milk proteins such as lactoferrin.

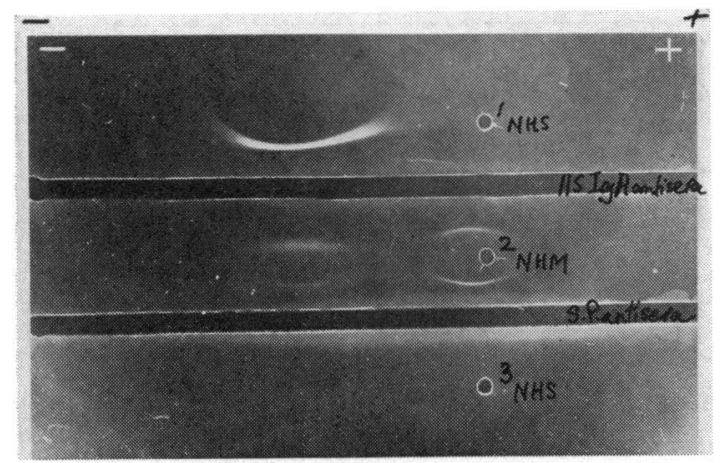

Fig 1 Immunoelectrophoresis showing monospecific precipitin lines between normal human serum $(N H S)$ in wells 1 and 3 , normal defatted milk (NHM) in well 2 and 11S IgA or secretory piece. Secretory piece antiserum showed no reaction with normal human serum.

The indirect immunofluorescence technique was used as follows: sections $5 \mu$ thick were cut from each biopsy at $-20^{\circ} \mathrm{C}$ on a cryostat, fixed for 15 minutes in acetone, and washed for 45 minutes with three changes of phosphate-buffered saline (PBS) $\mathrm{pH} \mathrm{7 \cdot 3.} \mathrm{The} \mathrm{sections} \mathrm{were} \mathrm{then} \mathrm{incubated} \mathrm{for} 30$ to 40 minutes with antiserum to $11 \mathrm{~S} \operatorname{IgA}$ or to secretory piece followed by a 45-minute wash in phosphatebuffered saline. The slides were stained for 45 minutes with fluorescein-isothiocyanate (FITC) conjugated antisheep immunoglobulin previously diluted and absorbed with liver powder. This was followed by a further 45 -minute wash in phosphate-buffered saline before mounting the sections in Polarfluor B. Slides were stored at $+4^{\circ} \mathrm{C}$.

In addition some sections were treated with an antiserum to lactoferrin (Nordic Pharmaceuticals) because it had previously been reported (Tomasi and Bienenstock, 1968) that there is a possibility of cross reaction between 11S IgA or secretory piece antisera and lactoferrin. The sections stained for the presence of lactoferrin showed fluorescence of goblet cells only, verified by simultaneous examination of the sections with phase-contrast illumination and incident light fluorescence. This contrasted with the characteristic staining pattern in the upper third of epithelial cells seen with $11 \mathrm{~S} \operatorname{IgA}$ and secretory piece antisera.

The direct staining technique using FITC conjugated 7S IgA, IgM, and IgG antisera (Wellcome reagents) was employed for the demonstration of immunoglobulins in the plasma cells of the lamina propria. The specificity of these antisera had been tested previously (unpublished data) by blocking the reaction, ie, incubating the tissue with unconjugated antiserum before staining. The blocking reactions only occurred when the unconjugated and corjugated antisera were of the same immunoglobulin class.

For most specimens, both techniques were repeated and reproducible results were obtained. The antisera to $7 \mathrm{~S} \operatorname{IgA}$ and $11 \mathrm{~S} \operatorname{IgA}$ were found to be specific on immunofluorescence for their particular immunoglobulin class alone. However, it seemed probable that the antiserum to secretory piece reacted with secretory piece contained in $11 \mathrm{~S}$ IgA and not only with the free molecule.

All sections were studied in random order on the day of preparation or the following day with a Leitz Orthoplan microscope. Between two and six slides of each type were studied and graded by one of us, without prior knowledge of the particular antisera used. The degree of staining of the upper part of epithelial cells, basement membrane, and connective tissue with $11 \mathrm{~S}$ IgA and secretory piece antisera was expressed as strongly positive $(++)$, positive $(+)$, or weakly positive $( \pm)$. The number of plasma cells stained with 7S IgA, IgM, and IgG antisera was graded 1 to 5 , the normal values for this laboratory being 4 for $7 \mathrm{~S} \operatorname{IgA}, 3$ for $\operatorname{IgM}$, and 1 or less for IgG.

\section{Results}

UNTREATED COELIAC DISEASE

In untreated coeliac patients (nos. 1-4) fluorescent staining with antisera to $11 \mathrm{~S} \operatorname{IgA}$ (fig 2) and secretory piece was seen in the basement membrane of surface and crypt epithelial cells and the surrounding connective tissue as well as in the upper third of epithelial cells where it is normally found (table I). Patient no. 5, treated with steroids but not with a gluten-free diet, showed staining with $11 \mathrm{~S} \operatorname{IgA}$ and secretory piece antisera of epithelial cells and basement membrane but not connective tissue. Patient 


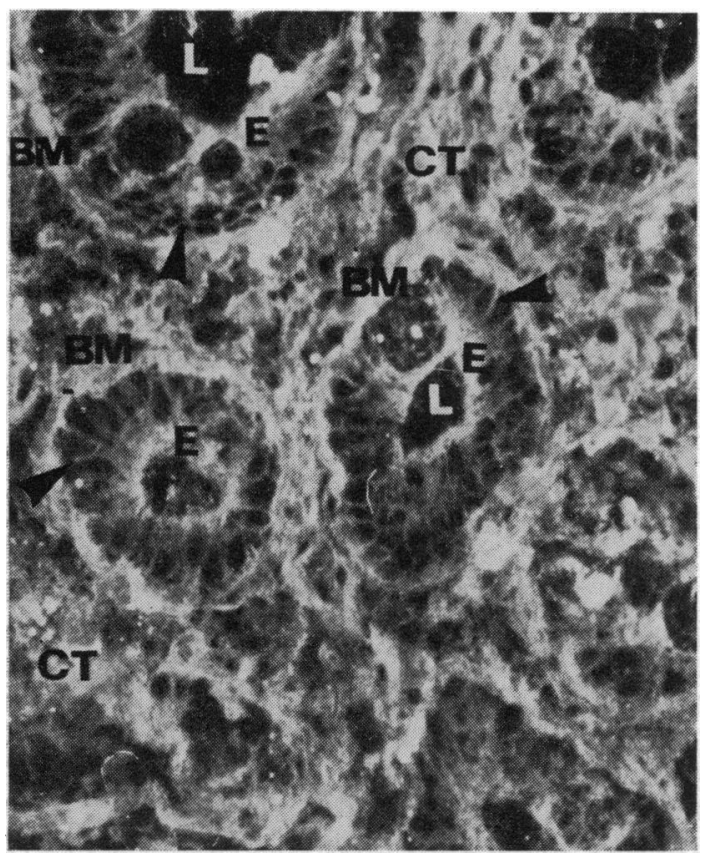

Fig 2 Jejunal mucosa from an untreated coeliac patient (no. 1) stained with antiserum to $11 S \mathrm{SgA}$. Bright fluorescence is seen in the upper third of epithelial cells (E), basement membrane (BM), and connective tissue (CT) and the intercellular spaces appear outlined (arrows).

$\mathrm{L}=$ crypt lumen. Approximately $\times 250$.

no. 6, inadequately treated with a gluten-free diet, showed a similar distribution of fluorescence to the untreated group but staining of the connective tissue with anti-secretory piece was absent. All six patients showed staining of the intercellular spaces between epithelial cells with both $11 \mathrm{~S} \operatorname{IgA}$ and secretory piece antisera.

\section{TREATED COELIAC DISEASE}

In our five treated coeliac patients (nos. 1 and 4 repeated after treatment and nos. 7, 8, and 9) staining with antisera to $11 \mathrm{~S}$ IgA and secretory piece was mainly confined to the upper third of epithelial cells, ie, normal distribution. The exception was patient no. 1 in whom connective tissue staining was observed with $11 \mathrm{~S}$ IgA and secretory piece antisera. He had been treated with a gluten-free diet for only three months, whereas all the other patients had been on the diet for more than 12 months. None of the well treated patients showed staining of the intercellular spaces.

The distribution of staining with antisera to $11 \mathrm{~S}$ IgA and secretory piece seemed to be related to the histological state of the jejunal mucosa in the coeliac patients. In those patients with a subtotal villous atrophy, staining of the basement membranes and connective tissue as well as the upper third of the epithelium was observed. In those with milder mucosal abnormalities (partial villous atrophy), where at least most of the gluten was eliminated from the diet, the 11S IgA and secretory piece showed a normal distribution, ie, in the epithelial cells only.

\section{CONTROL PATIENTS}

In our control patients 10-13 (table II) staining for $11 \mathrm{~S} \operatorname{IgA}$ (fig 3) and secretory piece was localized to the upper third of the epithelial cells only and was not seen in the intercellular spaces, basement membranes, or connective tissue. Similar staining of epithelial cells in the hypo- and agammaglobulinaemic patients (nos. 14 to 17) showed the presence of secretory piece despite an absence or virtual absence of 7S IgA in the mucosa.

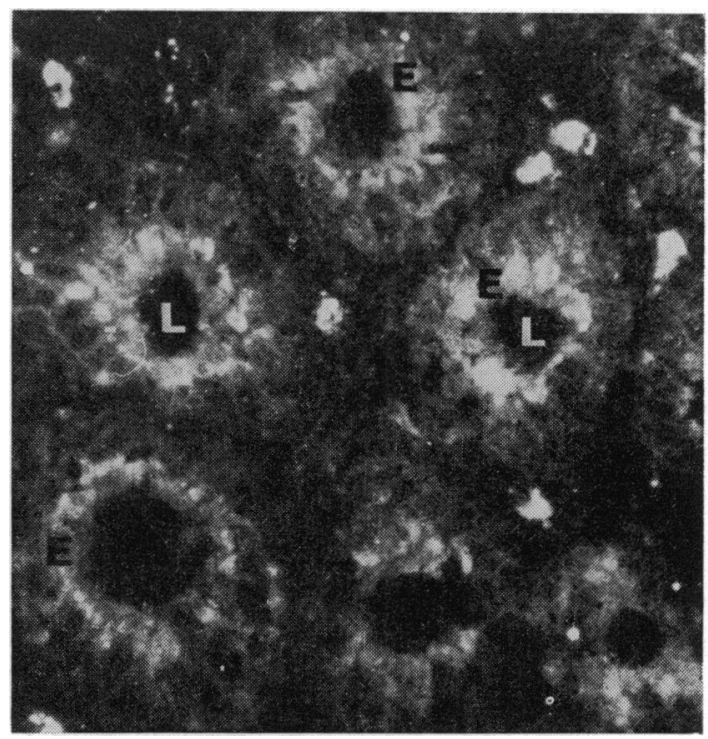

Fig 3 Jejunal mucosa from a control patient (no. 10) stained with $11 S \operatorname{IgA}$ antiserum. Only the upper third of epithelial cells (E) is fluorescent. The bright spots in the lamina propria are autofluorescent eosinophils.

$\mathrm{L}=$ crypt lumen. Approximately $\times 250$.

\section{S IgA IgM, AND IgG}

Basement membrane and connective tissue staining was seen with $7 \mathrm{~S}$ IgA in the untreated coeliacs $(1,2$, and 3$)$ but not in adequately treated patients $(1,4,7,8,9)$ nor in the normal controls $(10$ to 13$)$.

The number of $7 \mathrm{~S} \mathrm{IgA} \mathrm{and} \mathrm{IgM} \mathrm{containing} \mathrm{plasma}$ 
cells was increased in only one patient (no. 3, an untreated coeliac) who also had high levels of serum immunoglobulins. Patient no. 9, a well treated coeliac, had a reduced number of 7S IgA plasma cells in the lamina propria and she also had a low serum IgA level. An increase of IgG-producing plasma cells was noted in four out of five coeliacs not treated with a gluten-free diet but in none of the treated coeliac or control patients. Connective tissue staining with IgG antisera was found in all our patients except those with a serum IgG deficiency and was thought to be non-specific, as noted by us before (Shiner and Ballard, 1972a).

\section{Discussion}

This study has confirmed the localization of secretory piece to the upper part of the epithelial cells of the normal jejunal mucosa, as first proposed by Tourville et al (1969). The pathway of IgA from plasma cell to lumen suggested by these authors is shown in figure 4 (pathway $A$ ). The 7S IgA produced by local plasma cells is transported through the basement membrane of crypt and surface epithelium and passes either into the intercellular spaces or directly into the lower part of the epithelial cells. Dimerization and combination with secretory piece is thought to occur in the intercellular spaces. Because of the tight junctions between epithelial cells the 11S IgA formed in the intercellular spaces must enter the upper part of the epithelial cells before reaching the lumen.

Our hypothesis for the normal production of $11 \mathrm{~S}$ IgA differs from the above and is shown as pathway B. It is based on the evidence that in our normal patients staining of the intercellular spaces was observed with 7S IgA but not with 11S IgA or secretory piece antisera, and that staining of the upper third of the epithelium was seen with 11S IgA and secretory piece but not $7 \mathrm{~S} \operatorname{IgA}$ antisera. It is therefore proposed that the locally produced $7 \mathrm{~S} \mathrm{IgA}$ passes through the intercellular spaces to enter the upper third of the epithelium where it combines with secretory piece to form $11 \mathrm{~S}$ IgA. This is then transported across the microvilli into the lumen.

On the basis of our findings in the untreated coeliac patients, an additional pathway $C$ is suggested which may occur in pathological states. In this, a 'backflow' of 11S IgA from the epithelium to the lamina propria occurs as shown by $11 \mathrm{~S}$ IgA and secretory piece staining of intercellular spaces, basement membrane, and connective tissue. The available antiserum to secretory piece unfortunately does not distinguish between the free molecule and that which is part of the $11 \mathrm{~S} \operatorname{IgA}$. Therefore the secretory piece staining is probably due to the presence of secretory piece in $11 \mathrm{~S}$ IgA, although the possibility that a backflow of free secretory piece

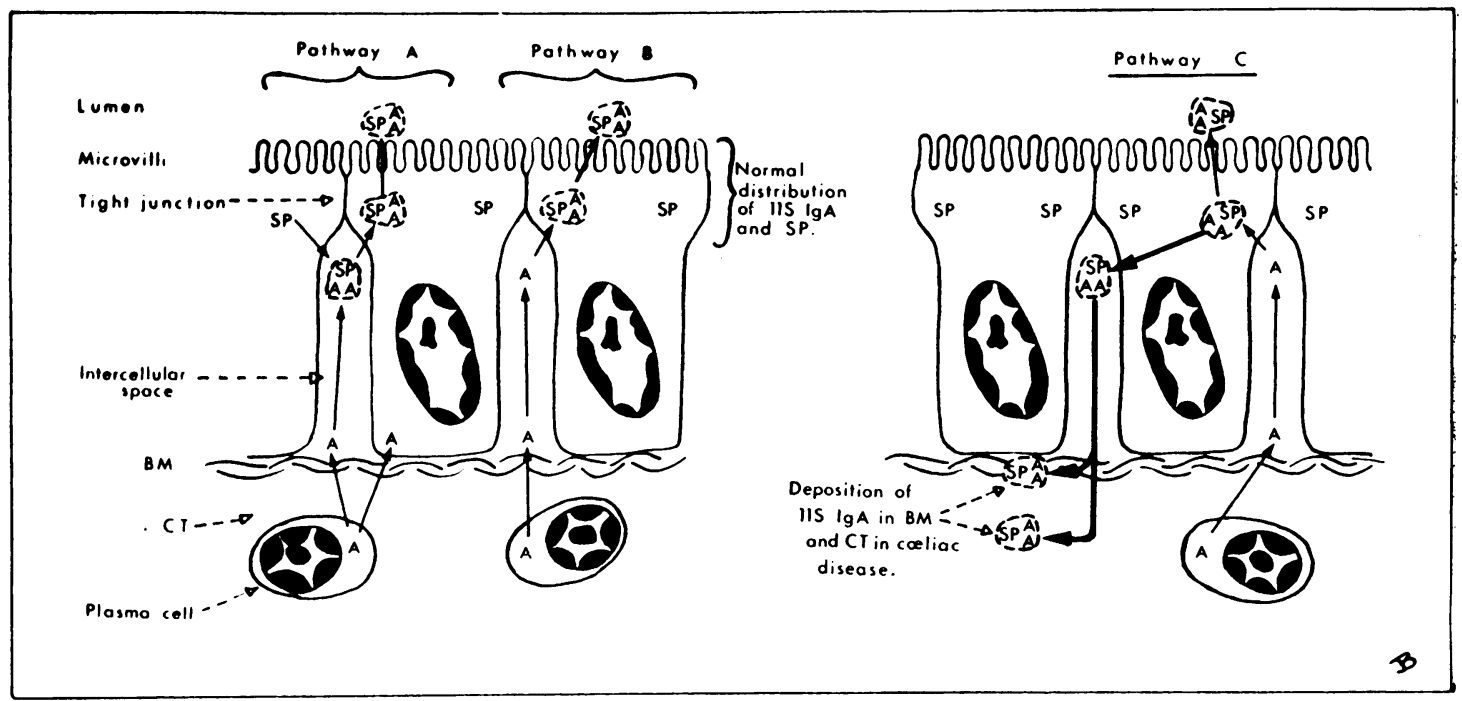

Fig 4 Diagram showing the formation and distribution of $11 S \operatorname{IgA}$ in the region of the epithelium. For explanation see text.

$\mathrm{BM}=$ basement membrane.

$\mathrm{CT}=$ connective tissue.

$\mathrm{A}=7 S \operatorname{Ig} A$

$\mathrm{SP}=$ secretory piece.
$\mathrm{A}>S P=11 S \operatorname{Ig} A$. 
also occurs cannot be ruled out. The exact site of formation of $11 \mathrm{~S} \mathrm{IgA} \mathrm{in} \mathrm{coeliac} \mathrm{disease} \mathrm{is} \mathrm{not} \mathrm{known}$ but probably occurs in the upper third of epithelial cells as in normal patients although it could also be formed between epithelial cells, in the basement membrane, or in connective tissue. In the last two sites, 11S IgA and 7S IgA may be involved in the formation of immune complexes with antigens such as gluten. This is supported by the demonstration of fluorescent staining of the lamina propria with antisera to these factors in untreated coeliac patients but not in treated or control patients. A similar localization was previously demonstrated for 7S IgA in treated coeliac children following gluten challenge (Shiner and Ballard, 1972b) and ultrastructural studies on the same patients showed cytopathological changes in the basement membrane and connective tissue (Shiner, 1973).

The removal of gluten from the diet of coeliac patients apparently stops the backflow of $11 \mathrm{~S} \operatorname{IgA}$ into the lamina propria so that the normal pathway $B$ remains. The localization of $11 \mathrm{~S} \mathrm{IgA}$ and secretory piece in well treated coeliac patients is indistinguishable from normal.

The demonstration of secretory piece in the epithelial cells of our patients with a- or hypogammaglobulinaemia is in accordance with the findings of others (Brown, Butterfield, Savage, and Tada, 1972) and indicates that epithelial cells produce secretory piece regardless of any deficiency of local or systemic IgA.

Plasma cell IgM was not consistently increased in any of our groups of patients, unlike Douglas, Crabbe, and Hobbs (1970) who reported an increased density of IgM-containing plasma cells in untreated coeliac patients.

IgG-containing plasma cells were usually increased in the mucosae of our untreated coeliac patients and this was also reported by Søltoft (1970).

The evidence from this, and our previous publication, is very suggestive of important subephithelial events occurring in coeliac disease involving both 7S and $11 \mathrm{~S} \mathrm{IgA} \mathrm{in} \mathrm{response} \mathrm{to} \mathrm{antigenic} \mathrm{stimulation.}$ The demonstrated backflow of $11 \mathrm{~S} \operatorname{IgA}$ into the lamina propria in untreated coeliac disease would explain the increased serum levels of 11S IgA (Thompson, Asquith, and Cooke, 1969).

We are grateful to Dr Margot Shiner for permitting us to study her patients, and for her enthusiastic encouragement, and to $\mathrm{Dr} A$. D. B. Webster, Northwick Park Hospital, Harrow, Middlesex, for allowing us to include his patients with immune deficiencies. We also thank Dr J. Snoijink of Nordic Pharmaceuticals for providing us with the immunoelectrophoretic data.
References

Balázs, V., and Szöllösy, E. (1962). Studies on the virus neutralising capacity of antacid gastric juices. Experientia (Basel),18,515-516.

Brandtzaeg, P. (1971). Human secretory immunoglobulins. V. Occurrence of secretory piece in human serum. J. Immunol, 106, 318-323.

Brown, W. R., Butterfield, D., Savage, D., and Tada, T. (1972). Clinical, microbiological and immunological studies in patients with immunoglobulin deficiencies and gastrointestinal disorders. Gut, 13, 441-449.

Brown, W. R., Newcomb, R. W., and Ishizaka, K. (1970). Proteolytic degradation of exocrine and serum immunoglobulins. J. clin. Invest., 49, 1374-1380.

Cederblad, G., Johannson, B. G., and Rymo, L. (1966). Reduction and proteolytic degradation of immunoglobulin A from human colostrum. Acta chem. scand., 20, 2349-2357.

Davis, S. D., Bierman, C. W., Pierson, W. E., Mass, C. W., and Iannetta, A. (1970). Clinical nonspecificity of milk coproantibodies in diarrheal stools. New Engl. J. Med., 282, 612-613.

Douglas, A. P., Crabbé, P. A., and Hobbs, J. R. (1970). Immunochemical studies of the serum, intestinal secretions and intestinal mucosa in patients with adult celiac disease and other forms of the celiac syndrome. Gastroenterology, 59, 414-425.

Ferguson, A., and Carswell, F. (1972). Precipitins to dietary proteins in serum and upper intestinal secretions of coeliac children. Brit. med. J., 1, 75-77.

Girard, J. P., and Kalbermatten, A. de (1970). Les immunoglobulines dans les sécrétions duodeno-pancréatiques et la bile. Schweiz. med. Wschr., 100, 336-338.

Hanson, L. A., and Johannson, B. G. (1967). Studies on secretory IgA. In Gamma Globulins: Structure and Control of Biosynthesis: Proceedings of the Third Nobel Symposium, edited by J. Killander, pp. 141-151. Interscience, New York, Almquist and Wiksel, Stockholm.

Lipton, M. M., and Steigman, A. J. (1963). Human coproantibody against polioviruses. J. infect. Dis., 112, 57-66.

Loeb, P. M., Strober, W., Falchuk, Z. M., and Laster, L. (1971). Incorporation of $\mathrm{L}$-leucine- ${ }^{14} \mathrm{C}$ into immunoglobulins by jejunal biopsies of patients with celiac sprue and other gastrointestinal diseases. J. clin. Invest., 50, 559-569.

Parkin, D. M., McClelland, D. B. L., O'Moore, R. R., Percy-Robb, I. W., Grant, I. W. B., and Shearman, D. J. C. (1972). Intestinal bacterial flora and bile salt studies in hypogammaglobulinaemia. Gut, 13, 182-188.

Shiner, M. (1973). Ultrastructural changes suggestive of immune reactions in the jejunal mucosa of coeliac children following gluten challenge. Gut, 14, 1-12.

Shiner, M., and Ballard, J. (1972a). Dermatitis herpetiformis-a disorder of immunity? (Letter). Lancet, 1, 796.

Shiner, M., and Ballard, J. (1972b). Antigen-antibody reactions in the jejunal mucosa in childhood coeliac disease after gluten challenge. Lancet, 1, 1202-1205.

Søltoft, J. (1970). Immunoglobulin-containing cells in non-tropical sprue. Clin. exp. Immunol., 6, 413-420.

South, M. A., Cooper, M. D., Wollheim, F. A., Hong, R., and Good, R. A. (1966). The IgA system. 1. Studies of the transport and immunochemistry of IgA in the saliva. J. exp. Med., 123, 615627.

Steward, M. W. (1971). Resistance of rabbit secretory IgA to proteolysis. Biochim. biophys. Acta (Amst), 236, 440-449.

Thompson, R. A., and Asquith, P. (1970). Quantitation of exocrine IgA in human serum in health and disease. Clin. exp. Immunol., 7, 491-500.

Thompson, R. A., Asquith, P., and Cooke, W. T. (1969). Secretory IgA in the serum. Lancet, 2, 517-519.

Tomasi, T. B., Jr., and Bienenstock, J. (1968). Secretory immunoglobulins. Advanc. Immunol., 9, 1-96.

Tomasi, T. B., Tan, E. M., Solomon, A., and Prendergast, R. (1965). Characteristics of an immune system common to certain external secretions. J. exp. Med., 121, 101-124.

Tourville, D. R., Alder, R. H., Bienenstock, J., and Tomasi,T. B., Jr. (1969). The human secretory immunoglobulin system: immunohistological localisation of $\gamma \mathrm{A}$, secretory 'piece' and lactoferrin in normal human tissues. J. exp. Med., 129, 411-429.

Tourville, D., Beinenstock J., and Tomasi, T. B., Jr. (1968). Natural antibodies of human serum, saliva and urine reactive with Escherichia coli. Proc. soc. exp. Biol. (N.Y.), 128, 722-727.

Waldman, R. H., Mach, J. P., Stella, M. M., and Rowe, D. S. (1970). Secretory IgA in human serum. J. Immunol., 105, 43-47. 